\title{
Predicting the fabric width of single jersey cotton knitted fabric using appropriate software
}

\author{
DOI: 10.35530/IT.070.06.1597
}

\section{ABSTRACT - REZUMAT}

\section{Predicting the fabric width of single jersey cotton knitted fabric using appropriate software}

Prediction of any property of the material has attracted the attention of many scientists all over the world in order to produce better products. Information Technology (IT) field has many applications and plays dominant role in the production of various products in the industry. Knitted fabric should satisfy a number of requirements of consumer. Fabric width is a very important property which affects knitted fabric comfort properties. The deviation from the fabric width will either lead to more consumption of raw material or affect profit of the company. Hence, controlling the width of the fabric has an adverse effect on company's profit and usage of raw materials. An investigation of the prediction of the width of the single jersey cotton knitted fabric in a fully relaxed state using Data mining technique in Rough set Computational based Priority Prediction Model (RCPPM) is reported. The inputs were yarn count, machine diameter, required GSM, machine gauge, actual yarn count, lea weight, lea strength, twist multiplier, loop length, course per $\mathrm{cm}$, wales per $\mathrm{cm}$, length shrinkage, width shrinkage, and fabric width. The real-time textile dataset consisted of 7,505 single jersey cotton knitted fabric samples. The results showed that the fabric width obtained by using aforesaid model was found to yield very accurate values and compared favourably with the measured ones. This study will lead to the production of the knitted fabric with better comfort and dimensional stability.

Keywords: data mining, dimensional stability, IT, prediction model, rough set, textile dataset

\section{Proiectarea lățimii tricotului glat din bumbac utilizând software-ul adecvat}

Predicția oricărei proprietăți a materialului a atras atenția multor oameni de știință din întreaga lume pentru a obţine produse performante. Domeniul Tehnologiei Informației (IT) are multe aplicații și joacă un rol dominant în fabricarea de produse diverse din industrie. Materialul tricotat ar trebui să satisfacă o serie de cerințe ale consumatorului. Lățimea tricotului este o proprietate foarte importantă, care influenţează proprietățile de confort. Abaterea de la lățimea tricotului va conduce fie la un consum mai mare de materie primă, fie va afecta profitul companiei. Prin urmare, controlul lățimii tricotului are efect negativ asupra profitului și utilizării materiei prime ale companiei. Este studiată predicţia lățimii tricotului glat din bumbac într-o stare complet relaxată, folosind tehnica de extragere a datelor în Modelul de predicție cu prioritate bazat pe calcul aproximativ (RCPPM). Intrările au fost reprezentate de finețea firului, diametrul mașinii, GSM-ul necesar, fineţea mașinii, finețea reală a firului, masa, rezistența la tracţiune, multiplicatorul de torsiune, lungimea buclei, rânduri per cm, șiruri de ochiuri per cm, contracția lungimii, contracția lățimii și lățimea tricotului. Setul de date real a constat din 7.505 de probe de tricot glat din bumbac. Rezultatele au arătat că lățimea tricoturilor obținute prin utilizarea modelului menționat anterior a înregistrat valori foarte precise și comparabile cu cele măsurate. Acest studiu va duce la producerea de tricoturi cu proprităţi îmbunătăţite de confort și stabilitate dimensională.

Cuvinte-cheie: extragerea datelor, stabilitate dimnesională, IT, model de predicție, set aproximativ, set de date

\section{INTRODUCTION}

It is very important to take into account the optimum width of the knitted fabric for tailoring purposes. Changes in fabric width will have an adverse effect on the comfort properties of fabrics and spoil the reputation of the company that manufactures them. The software for predicting fibre areal density was developed by Gravas et al. [1]. Panda et al. [2] dealt with the prediction of fabric width of single jersey cotton knitted fabrics by an artificial neural network. A number of publications on soft computing, data mining techniques and others are available [3-12]. Kalkanci et al. [13] have predicted the dimensional change in finished fabric through an artificial neural network. The usefulness of the Starfish technique has been pointed out by Hossain et al. [14]. The fabric width is calculated for single jersey cotton knitted fabric using the following formulae [15]

$$
\begin{aligned}
& \text { Fabric width }(\mathrm{cm})= \\
& \quad=\text { number of needles * wale spacing }
\end{aligned}
$$

Fabric width $(\mathrm{cm})=$ course length $/ K_{w}$, where course length $=n$ *I ( $n$ - number of needles, $I-$ loop length in $\mathrm{cm}, K_{w}-$ fabric dimensional constant)

$$
\begin{aligned}
& \text { Fabric width }(\mathrm{cm})= \\
& \quad=\text { number of needles * yarn diameter }(\mathrm{cm}) * 4
\end{aligned}
$$

This paper is concerned with the prediction of fabric width using new approaches such as rough set and data mining technique which have not been exploited by previous research workers. 


\section{EXPERIMENTAL}

For this study, extensive data were collected from Tirupur knitting units. From those data, we have taken 7,505 fabric sample values of dataset. The summary of the dataset is given in table 1. It should be mentioned that all the fabric samples considered are plain jersey, jet dyed and made of $40^{\mathrm{s}}$ (15 Tex) carded cotton yarns in a ring frame. They were fully relaxed as per the Starfish recommendations. Out of 7,505 fabric sample values of dataset, one group consisted of 6,432 fabric sample values of dataset using for the software learning (training purpose) and another group consisted of 1,073 fabric sample values of dataset for testing purposes. A list of parameters used for training and for testing is given in tables 2 and 3 .
Rough Computational based Priority Prediction Model (RCPPM)

Data science is a process used to discover hidden patterns from a large amount of data using statistical and machine learning approaches. Data science classification techniques are used in a number of applications like customer analytics, marketing analytics, water quality analytics, healthcare analytics, textile production analytics, manufacturing analytics and textile waste analytics. The proposed idea is to predict the fabric width based on the various parameters of textile data using rough computational based priority prediction model (RCPPM). A novel Gaussian Bayesian method is one of the important data science classification methods which are used to develop the proposed prediction model. Figure 1 shows the architecture of the proposed framework.

SUMMARY OF PARAMETERS OF ENTIRE DATASET (FOR 7,505 FABRIC SAMPLES)

\begin{tabular}{|l|c|c|c|c|}
\hline \multicolumn{1}{|c|}{ Parameters } & Mean & $\begin{array}{c}\text { Standard } \\
\text { deviation }\end{array}$ & $\begin{array}{c}\text { Maximum } \\
\text { value }\end{array}$ & $\begin{array}{c}\text { Minimum } \\
\text { value }\end{array}$ \\
\hline Nominal linear density (tex) & 14.76 & - & 14.76 & 14.76 \\
\hline Actual linear density (tex) & 15.32 & 0.33 & 17 & 1.55 \\
\hline Lea weight (gms) & 1.68 & 0.04 & 1.87 & 33.68 \\
\hline Lea strength (lbs) & 57.29 & 8.27 & 78.49 & 0 (due to missing values) \\
\hline Twist multiplier (tpcm* tex ${ }^{0.5}$ ) & 35.10 & 0.38 & 36.98 & 21.67 \\
\hline Loop length (mm) & 2.18 & 0.05 & 2.42 & 16.48 \\
\hline Course per cm & 24.98 & 0.72 & 27.98 & 357.22 \\
\hline Wales per cm & 18.31 & 0.39 & 19.88 & 0.02 \\
\hline Stitch density (cm ${ }^{2}$ ) & 457.71 & 23.05 & 556.30 & 1.87 \\
\hline Tightness factor (tex ${ }^{0.5 *} \mathrm{~mm}^{-1}$ ) & 1.80 & 0.03 & 5 & 0 (due to missing values) \\
\hline Length shrinkage (\%) & 4.99 & 0.06 & 5 & 0 (due to missing values) \\
\hline Width shrinkage (\%) & 4.99 & 0.06 & 19 & 0 (due to missing values) \\
\hline Machine diameter (inches) & 18.99 & 0.22 & 24 & 0 (due to missing values) \\
\hline Machine gauge (inches) & 23.99 & 0.28 & 157.31 & 1.18 (due to missing values) \\
\hline Actual GSM & 152.43 & 2.11 & 88.91 & 80.28 \\
\hline Fabric width (cm) & 83.67 & 0.89 & & \\
\hline
\end{tabular}

SUMMARY OF PARAMETERS USED FOR TRAINING DATASET (FOR 6,432 FABRIC SAMPLES)

\begin{tabular}{|l|c|c|c|c|}
\hline \multicolumn{1}{|c|}{ Parameters } & Mean & $\begin{array}{c}\text { Standard } \\
\text { deviation }\end{array}$ & $\begin{array}{c}\text { Maximum } \\
\text { value }\end{array}$ & $\begin{array}{c}\text { Minimum } \\
\text { value }\end{array}$ \\
\hline Actual linear density (tex) & 15.31 & 0.33 & 17 & 14.10 \\
\hline Lea weight (gms) & 1.68 & 0.04 & 1.87 & 68.30 \\
\hline Lea strength (Ibs) & 57.28 & 8.31 & 78.49 & 33.68 \\
\hline Twist multiplier (tpcm* tex ${ }^{0.5}$ ) & 35.09 & 0.37 & 36.98 & 2.01 \\
\hline Loop Length (mm) & 2.18 & 0.05 & 2.42 & 21.67 \\
\hline Course per cm & 24.99 & 0.72 & 27.98 & 16.48 \\
\hline Wales per cm & 18.32 & 0.39 & 19.88 & 19 \\
\hline Machine diameter (inches) & 19 & - & 19 & 24 \\
\hline Machine gauge (inches) & 24 & - & 24 & 80.28 \\
\hline Fabric width (cm) & 83.67 & 0.89 & 88.91 & \\
\hline
\end{tabular}


SUMMARY OF PARAMETERS USED FOR TESTING DATASET (FOR 1,073 FABRIC SAMPLES)

\begin{tabular}{|l|c|c|c|c|}
\hline \multicolumn{1}{|c|}{ Parameters } & Mean & $\begin{array}{c}\text { Standard } \\
\text { deviation }\end{array}$ & $\begin{array}{c}\text { Maximum } \\
\text { value }\end{array}$ & $\begin{array}{c}\text { Minimum } \\
\text { value }\end{array}$ \\
\hline Actual linear density (tex) & 15.34 & 0.33 & 16.95 & 14.3 \\
\hline Lea weight (gms) & 1.68 & 0.04 & 1.86 & 68.13 \\
\hline Lea strength (Ibs) & 57.36 & 8.08 & 78.49 & 33.91 \\
\hline Twist multiplier (tpcm* tex ${ }^{0.5}$ ) & 35.13 & 0.38 & 36.92 & 2.03 \\
\hline Loop length (mm) & 2.18 & 0.05 & 2.41 & 21.76 \\
\hline Course per cm & 24.91 & 0.73 & 27.43 & 16.54 \\
\hline Wales per cm & 18.28 & 0.39 & 19.60 & 19 \\
\hline Machine diameter (inches) & 19 & - & 19 & 24 \\
\hline Machine gauge (inches) & 24 & - & 24 & 81.28 \\
\hline Fabric width (cm) & 83.89 & 0.82 & 88.30 & \\
\hline
\end{tabular}

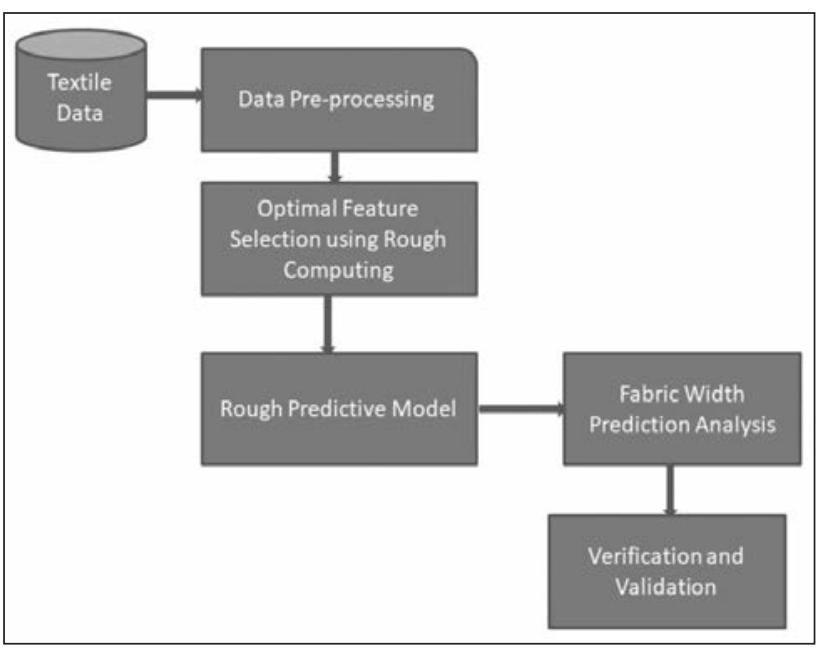

Fig. 1. Rough Computational Based Priority Prediction Model Architecture

\section{Data preprocessing}

Data preprocessing under data mining plays a vital role in data analysis. Various data preprocessing methods such as data cleaning, data transformation, data integration, and data reduction were used to ensure the quality data for data mining models. In data mining, the variables measured at different scales do not contribute equally to the data analysis. To overcome this problem, we need to transform the data to comparable scale values. Data standardizing is one type of data transformation method which converts all variables value into the same scale. The appropriate standardization method depends on the dataset and the conventions of a particular field of study.

In this research work, the textile datasets are preprocessed by using various data preprocessing methods. Z-score data standardization method is used to normalize the textile data.

$$
N T_{D}=\frac{T_{D}-\mu_{T_{D}}}{\sigma_{T_{D}}}
$$

where: $N T_{D}$ is normalized value of the textile attributes;
$T_{D}$ - the actual textile attributes value;

$\mu_{T_{D}}$ - mean of textile attributes value; $\sigma_{T_{D}}$ - standard deviation of textile attributes

Z-score data standardization method works better for large datasets and provides proper scaling than minmax and decimal scaling methods.

\section{Optimal attribute selection using rough set computing}

Soft Computing plays a significant role in scientific applications. Rough set [11, 16, 17, 18, 21] and fuzzy are the two hands of soft computing. The information system consists of many attributes, and these attributes are used to predict the class label. Selection of significance attribute(s) for the classification process yields a good prediction model. Attribute selection process directs to electing a subset of attributes from the broad set of attributes. The aim of the attribute selection is to find the important attribute, remove the irrelevant attribute and construct a novel predictive model. The minimum computation time of the algorithm and excellent accuracy of the predictive model are the two significant advantages of attribute selection. The research community has studied intensively the attribute selection methods for various applications. In this research work, the rough set computing is applied to identify the important attributes from the large dataset of the textile information system.

\section{Rough set attribute dependency}

Attribute dependency in the rough set can be interpreted as the combination of objects in knowing the values of attributes. This checks the degree of dependency between the two attributes. Every attribute produces the indiscernibility among the given two rough sets. Indiscernibility relation concept in the rough sets defines the association between the set of attributes. The same indiscernible objects can be represented redundantly.

Let $U_{s}$ be the universe and let $R S \subseteq U_{s} \times U_{s}$ be an equivalence relation on $U_{s}$, called an indiscernibility 
relation. The pair $A=\left(U_{s}, R S\right)$ is called an approximation space. The lower and upper approximation of set $X$ with respect to $R S$ can be written as:

$$
\begin{aligned}
& \underline{R S}(X)=\left\{x \in U_{S}:[x]_{R S} \subseteq X\right\} \\
& \overline{R S}(X)=\left\{x \in U_{S}:[x]_{R S} \cap X \neq \varnothing\right\}
\end{aligned}
$$

where $[x]_{R S}=\left\{y \in U_{S} \mid x R S y\right\}$ is the equivalence class of $x$; if $[x]_{R S} \subseteq X$, then it is certain that $x \in X$; if $[x]_{R S} \subseteq X-\overline{R S}(X)$ then it is clear that $x \not \subset X$; $[x]_{R S} \subseteq X$ is said to be rough with respect to $R S$ iff $\underline{R S}(X) \neq \overline{R S}(X)$. Otherwise $X$ is $R S$-discernible. A set of attributes $B$ depends on the set of attributes $A$ is given as follows:

$$
A \Rightarrow B
$$

where the attributes of $B$ are uniquely determined by the values of attributes of $A$. $B$ completely depends on the values of $A$ if there exists in the functional dependency relationship in between them. The functional dependency depicts that both the $A$ and $B$ are subsets with each other. Suppose if $B$ depends completely on $C$ then with a degree of $k$ then it can be as $k(0<=k<=1)$ denoted by the positive region,

$$
A \Rightarrow{ }_{k} B
$$

where the positive region $C$ is given as

$$
\operatorname{POS}_{B}(A)=\underset{B \in I / \ln d}{\bigcup} \underline{R B}
$$

So for all the elements in the universe, $I$ in terms of $A$ and $B$ can be given as

$$
\gamma(A, B)=\left|\operatorname{POS}_{A}(B)\right| /|I|
$$

Here the dependency of $B$ on $A$ depends on the value of $k$; if $k=1$ then we can say that $B$ depends on $A$ completely and if $k<1$ then it states that $B$ depends on $A$ but partially. The $k$ expresses the blocks of partition $I / B$ with respect to $A$ and it is termed as the degree of dependency.

\section{Rough set based optimal attributes}

The optimal attributes are determined using the concept of reducts and core in rough set theory. Due to this indiscernibility relation, it becomes ease in finding the redundant values or the redundant attributes of a set. The several set approximation subsets of attributes, which exists in minimal are termed as reducts. The set of all the conditional attributes of set approximations that exists as a set is defined as a core, and in simple, it is the intersection of all the reducts to a set or a system considered. For example, let $T$ be a set of attributes and let the attribute $R$ be the subset of attribute $C$ then it is depicted as below:

$$
T=(U, R, D) / / \text { independent of } C
$$

Then the positive relation is given as

$$
\begin{aligned}
\operatorname{POS}_{R}(D) & =\operatorname{POS}_{C}(D) \\
\text { i.e. } \quad \operatorname{CORE}(C) & =\cap \operatorname{RED}(C)
\end{aligned}
$$

where $\operatorname{CORE}(C)$ defines all the conditional attributes and $\operatorname{RED}(C)$ defines all the set of reducts of attribute $C$. One of the approaches for these reducts or the conditional attributes is done dynamically and depicted by the decision tables. In these decision tables, the attributes are classified in two ways as relevant and often. When the attributes are more often repeated it is given as majority or relevant and the set of attributes appearing as common to the original sets in decision tables are given through as often.

\section{Priority Bayes Classifier}

The Data science has several classification algorithms like Support Vector Machine (SVM), Decision Tree, Back Propagation Neural Network (BP-NN), Rule-based Classification and Naïve Bayesian Classification. Although NN and SVM techniques offer reasonably good solutions for textile problems, researchers have also tried using the Naive Bayes algorithm. Naïve Bayes is one of the well-known and highly scalable classification algorithms, which uses Bayes' theorem to calculate conditional probabilities for the determination of unknown class values of samples. A Naive Bayesian classifier method is a set of a supervised learning algorithm based on applying Bayes' theorem with the "naive" assumption of liberty between each pair of features. Bayes' theorem states the following relationship for a given class variable and a dependent feature vector $x_{1}$ through $x_{n}$ :

$$
P\left(y / x_{1}, \ldots, x_{n}\right)=\frac{P(y) P\left(x_{1}, \ldots, x_{n} \mid y\right)}{P\left(x_{1}, \ldots, x_{n}\right)}
$$

- $P(y / x)$ is the posterior probability of decision attribute class $(y$, target) given predictor ( $x$, attributes).

- $P(y)$ is the prior probability.

- $P(x / y)$ is the likelihood which is the probability of predictor for a given class.

- $P(x)$ is the prior probability.

In our research work, the data were represented as a continuous attribute. To handle such a data, extension version of Naïve Bayes method is used to develop priority based prediction model. This extension of naive Bayes is called Gaussian Naive Bayes. It is also assumed that all the features are following a Gaussian distribution. Instead of assuming conditional independence of $x_{j}$, the dependence relation of $x_{j}$ is encoded in the covariance matrix as in Gaussian distribution $P(x / y)$.

$$
P(x / y)=\frac{1}{\sqrt{(2 \pi)^{D} \operatorname{det}(\Sigma)}} \exp \left(-\frac{1}{2}(x-\mu)^{T} \Sigma^{-1}(x-\mu)\right)
$$

where $\mu$ is mean, $\Sigma$ - covariance matrix and $D-\operatorname{dim}$ $(x)$. In the prediction model, the attributes are assigned priority based on the attribute significance or dependency approximation value while computing posterior probability as shown in table 4.

The rough computational based priority prediction model (RCPPM) algorithm is given below. 
PRIORITY ASSIGNMENT BASED ON ROUGH SET ATTRIBUTES SIGNIFICANCE APPROXIMATION

\begin{tabular}{|l|c|c|}
\hline Name of the attribute & $\begin{array}{c}\text { Attribute } \\
\text { significance } \\
\text { approximation } \\
\text { value }\end{array}$ & $\begin{array}{c}\text { Priority } \\
\text { assignment }\end{array}$ \\
\hline $\begin{array}{l}\text { Nominal linear density } \\
\text { (tex) }\end{array}$ & 0.20 & 10 \\
\hline $\begin{array}{l}\text { Actual linear density } \\
\text { (tex) }\end{array}$ & 1.00 & 1 \\
\hline Lea weight (gms) & 0.72 & 3 \\
\hline Lea strength (lbs) & 0.25 & 9 \\
\hline $\begin{array}{l}\text { Twist multiplier } \\
\text { (tpcm* tex }{ }^{0.5} \text { ) }\end{array}$ & 0.98 & 2 \\
\hline Loop length (mm) & 0.64 & 4 \\
\hline Course per cm & 0.30 & 8 \\
\hline Wales per cm & 0.30 & 7 \\
\hline $\begin{array}{l}\text { Length } \\
\text { shrinkage (\%) }\end{array}$ & 0.15 & 11 \\
\hline Width shrinkage (\%) & 0.15 & 12 \\
\hline $\begin{array}{l}\text { Machine diameter } \\
\text { (inches) }\end{array}$ & 0.35 & 5 \\
\hline Machine gauge (inches) & 0.35 & 6 \\
\hline
\end{tabular}

\section{Proposed RCPPM Algorithm}

\begin{tabular}{ll}
\hline Input: & $T_{D}:$ Textile Data, $n:$ number of attributes \\
Output: & $R C P P M$ Model
\end{tabular}

Step 1: Remove noisy and missing values using data preprocessing methods

Step 2: Standardize the textile data using Z-Score Normalization

$$
N T_{D}=\frac{T_{D}-\mu_{T_{D}}}{\sigma_{T_{D}}}
$$

Step 3: Select the optimal attribute for the prediction model from the large textile data

3.1. Calculate approximation values for all attributes using equation (17),

$\sigma_{(P, Z)}(a)=\frac{\left(\operatorname{card}\left(\operatorname{POS}_{p}(Z)\right)-\left(\operatorname{card}\left(\operatorname{POS}_{p-(a)}(Z)\right)\right)\right.}{\operatorname{card}(U)}$

3.2. Compare the approximation values of each attribute $a j$,

3.3. If both attributes are highly associated then remove the less approximation value attribute(s).

Step 4: For each $j=i+1$ to $n$ Do

4.1. Calculate a value for all class labels

$$
P\left(y / x_{1}, \ldots, x_{n}\right)=\frac{P(y) P\left(x_{1}, \ldots, x_{n} \mid y\right)}{P\left(x_{1}, \ldots, x_{n}\right)}
$$

4.2. Compare the class labels value and predict the fabric width. next $j$
In this research work, the existing Bayesian algorithm is modified and proposed novel rough computational based priority prediction model (RCPPM) algorithm as shown above. RCPPM algorithm has two parts: first part deals with selection of optimal attributes using rough computational based optimal attribute selection (RCOAS) method and second part deals with development of RCPPM prediction model. The real-time textile dataset $T_{D}$ may have missing values and these values are replaced by using missing value analysis. Then the dataset are first standardized (normalized) to overcome the deviation of the scale between the different attributes. Normalization is classified into range normalization-score and decimal scaling. In the proposed algorithm, the Z-score normalization $N T_{D}$ is applied to standardize the dataset. This process helps to improve the accuracy of the prediction model. Then the normalized dataset are given as input to RCOAS algorithm to find the optimal attribute(s) and the output of RCOAS algorithm is supplied to the Gaussian Naive Bayes based RCPPM algorithm to predict the fabric width. The RCPPM proposed model performance is compared with the ground truth textile dataset which is collected from the Tirupur knitting industry. Finally, the RCPPM performance is compared with various prediction models.

\section{RESULTS AND DISCUSSION}

Tirupur is one of the crucial textile export zones in Tamilnadu. The real-time dataset was collected from the Tirupur knitting industry. The summary of the entire dataset is shown in table 1, which consists entirely of 16 textile attributes. The first 15 are conditional attributes and fabric width $(\mathrm{cm})$ is a decision attribute. The data pre-processing procedures such as missing value analysis and data standardization are applied to produce reliable data. Z-score normalization was applied to textile dataset and the corresponding normalized values used for our proposed model. Feature/attribute selection is the most commonly used technique in data mining to reduce redundant or irrelevant data.

The proposed RCPPM algorithm is developed using matlab codes for finding the optimal attribute(s) and for prediction model to predict optimal fabric width for single jersey finished cotton knitted fabric. The first part of the proposed algorithm is to find optimal attributes among the various textile conditional attributes using rough set techniques. The attributes are to be classified based on the attribute significance value which we obtained through the computational program. From the table 5, It should be clear that some of the conditional attributes such as stitch density, tightness factor, actual GSM are not considered because of their less importance during optimal attribute selection and also observed that the significant attribute score of the width shrinkage and length shrinkage are less when compared to the other conditional attributes. Based on the rough set Core and Reduct concepts, all the above-said attributes are 
removed from the input knowledge data and also two reducts (set of 4 and 9 attributes) and one core (set of 4 attributes) are identified. Either use 4 or 9 attributes as optimal attributes based on attribute significance value with decision attribute fabric width as input knowledge data to the prediction model RCPPM.

Table 5

ROUGH SET BASED ATTRIBUTE SIGNIFICANCE APPROXIMATION VALUES

\begin{tabular}{|l|c|}
\hline \multicolumn{1}{|c|}{ Name of the attributes } & $\begin{array}{c}\text { Attribute } \\
\text { significance } \\
\text { approximation } \\
\text { values }\end{array}$ \\
\hline Nominal linear density (tex) & 0.20 \\
\hline Actual linear density (tex) & 1.00 \\
\hline Lea weight (gms) & 0.72 \\
\hline Lea strength (lbs) & 0.25 \\
\hline Twist multiplier (tpcm * tex ${ }^{0.5}$ ) & 0.98 \\
\hline Loop length (mm) & 0.64 \\
\hline Course per cm (CPcm) & 0.30 \\
\hline Wales per cm (WPcm) & 0.30 \\
\hline Length shrinkage (\%) & 0.15 \\
\hline Width shrinkage (\%) & 0.15 \\
\hline Machine diameter (inches) & 0.35 \\
\hline Machine gauge (inches) & 0.35 \\
\hline
\end{tabular}

Based on the RCOAS algorithm output, the optimal attributes obtained, are actual linear density (tex), twist multiplier (tpcm * tex ${ }^{0.5}$ ), lea weight (gms), loop length $(\mathrm{mm})$, machine diameter (inches), machine gauge (inches), WPcm, CPcm and lea strength (lbs) respectively from the supplied textile dataset as summarized in table 1. The importance of each textile attribute is shown in figure 2 based on their attribute significance value. Then the selected optimal

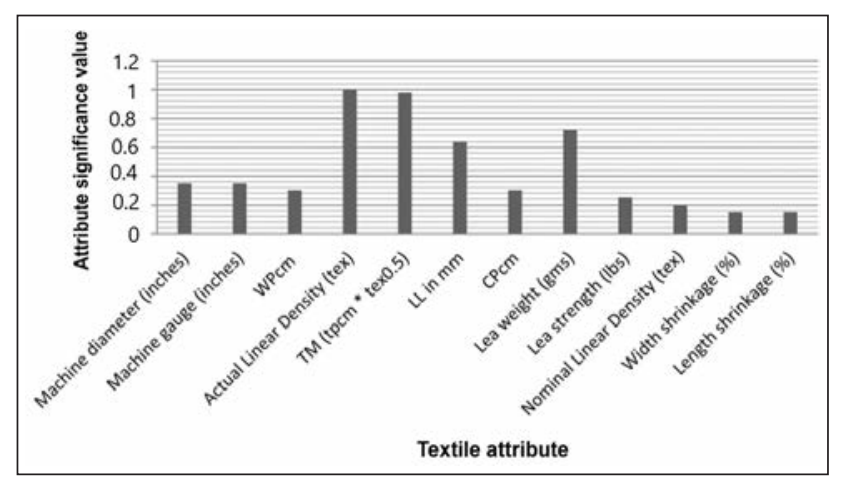

Fig. 2. Textile Attribute Vs Attribute significance value

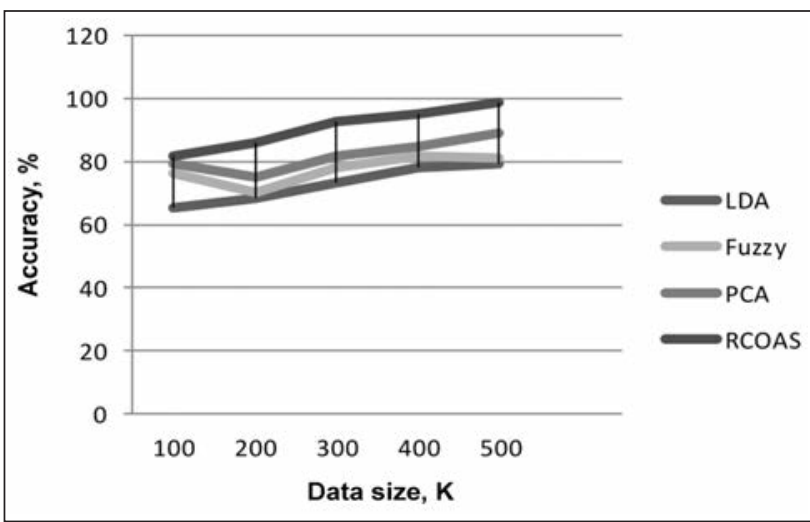

Fig. 3. Performance of various attribute selection methods

attribute(s) are supplied to the RCPPM prediction model to predict the value of fabric width.

Many feature selection methods are used by the research community in various engineering applications such as Principal Component Analysis (PCA) [19], Linear Discriminant Analysis (LDA) [20] and Fuzzy based analysis [21]. The performance of the proposed RCOAS method is compared with the above-said methods. The performance of the proposed method is better than other attribute selection methods as shown in the figure 3 .

Table 6

\begin{tabular}{|c|c|c|c|c|c|c|c|}
\hline \multicolumn{5}{|c|}{ PREDICTED VALUES OF FABRIC WIDTH FOR TESTING DATASET FABRIC SAMPLES } \\
\hline \multirow{2}{*}{$\begin{array}{c}\text { Sample } \\
\text { no. }\end{array}$} & $\begin{array}{c}\text { Actual value } \\
\text { of fabric } \\
\text { width }\end{array}$ & \begin{tabular}{c} 
ANN \\
\cline { 3 - 8 }
\end{tabular} & $\begin{array}{c}\text { Predicted } \\
\text { value }\end{array}$ & Error (\%) & $\begin{array}{c}\text { Predicted } \\
\text { value }\end{array}$ & Error (\%) & \multicolumn{3}{c|}{$\begin{array}{c}\text { Predicted } \\
\text { value }\end{array}$} & Error (\%) \\
\hline 1 & 83.06 & 83.009914 & 0.0603 & 83.01822 & 0.0503 & 83.024865 & 0.0423 \\
\hline 2 & 83.51 & 83.459726 & 0.0602 & 83.451375 & 0.0702 & 83.475677 & 0.0411 \\
\hline 3 & 84.25 & 84.190519 & 0.0706 & 84.190519 & 0.0706 & 84.206358 & 0.0518 \\
\hline 4 & 83.66 & 83.609385 & 0.0605 & 83.592653 & 0.0805 & 83.632810 & 0.0325 \\
\hline 5 & 83.85 & 83.799522 & 0.0602 & 83.824677 & 0.0302 & 83.813022 & 0.0441 \\
\hline 6 & 84.77 & 84.708541 & 0.0725 & 84.759403 & 0.0125 & 84.741856 & 0.0332 \\
\hline 7 & 82.53 & 82.467937 & 0.0752 & 82.486919 & 0.0522 & 82.503177 & 0.0325 \\
\hline 8 & 82.38 & 82.324146 & 0.0678 & 82.326617 & 0.0648 & 82.345894 & 0.0414 \\
\hline 9 & 84.42 & 84.363016 & 0.0675 & 84.37145 & 0.0575 & 84.382433 & 0.0445 \\
\hline 10 & 83.53 & 83.477960 & 0.0623 & 83.503019 & 0.0323 & 83.501850 & 0.0337 \\
\hline
\end{tabular}


Based on the optimal attribute selection, the prediction model was developed as second part of the RCPPM algorithm. The proposed RCPPM algorithm performance is compared with ANN (Artificial Neural Network) Model [8, 9, 10] and ANN with PSO [22] (Artificial Neural Network with Particle Swarm Optimization). All the prediction models are developed with 6,432 training fabric samples and tested with 1,073 testing fabric samples. The cross k-validation method is used to split the textile dataset accurately into training and testing to overcome the unbalanced dataset problem. The prediction is done based on various machine diameters such as 19, 20, 21, 22 and 23 inches. Table 6 contains the actual and predicted values of fabric width for a few testing dataset fabric samples from which it is apparent that predicted values compare favourably with experimental values which shows the reliability of our proposed prediction model RCPPM.

Various critical performance metrics are available to evaluate the performance of the proposed RCPPM model such as Root Mean Square Error (RMSE), Mean Square Error (MSE) and Absolute Error (AE). Our prediction model performance is evaluated using the MSE performance metric. Table 7 shows the MSE

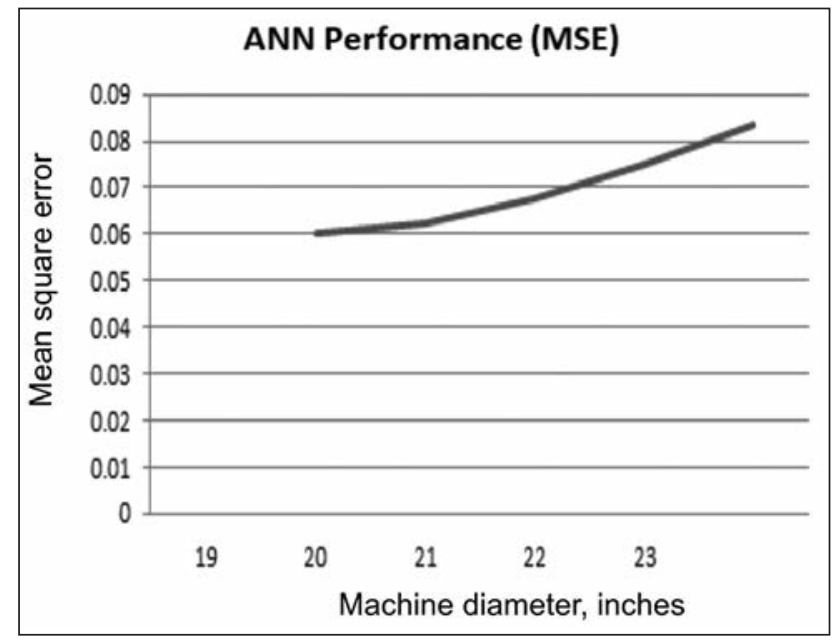

a

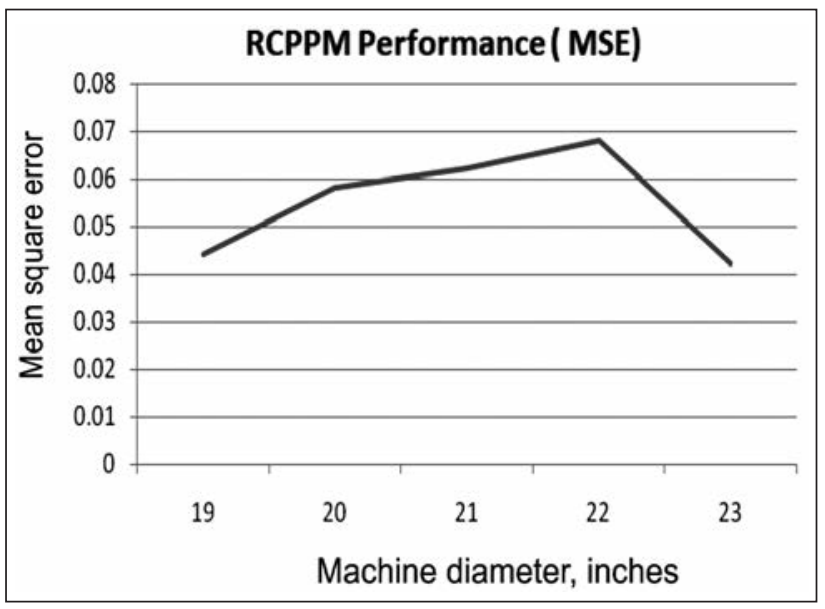

C

\begin{tabular}{|c|c|c|c|}
\hline \multicolumn{2}{|c|}{\begin{tabular}{c} 
Table 7 \\
\hline $\begin{array}{c}\text { COMPARISON OF RCPPM PERFORMANCE (MSE) } \\
\text { WITH OTHER PREDICTION MODELS }\end{array}$ \\
\hline $\begin{array}{c}\text { Machine } \\
\text { diameters } \\
\text { (inches) }\end{array}$
\end{tabular} ANN } & $\begin{array}{c}\text { ANN with } \\
\text { PSO }\end{array}$ & RCPPM \\
\hline 19 & 0.0602 & 0.054 & 0.044 \\
\hline 20 & 0.0621 & 0.057 & 0.058 \\
\hline 21 & 0.0678 & 0.106 & 0.062 \\
\hline 22 & 0.0752 & 0.072 & 0.068 \\
\hline 23 & 0.0836 & 0.081 & 0.0421 \\
\hline
\end{tabular}

value for ANN, ANN with PSO and RCPPM for 5 different machine diameters.

Figures 4, a-d show the performance of ANN, ANN with PSO, RCPPM, and comparison of all three prediction models based on MSE performance metric respectively. The MSE values change based on the machine diameter values. In the case of ANN model, the MSE value increases as the machine diameter value increases. The ANN model is optimized with PSO, where the MSE value is small for 19, 20 machine diameter, and it is very high when machine
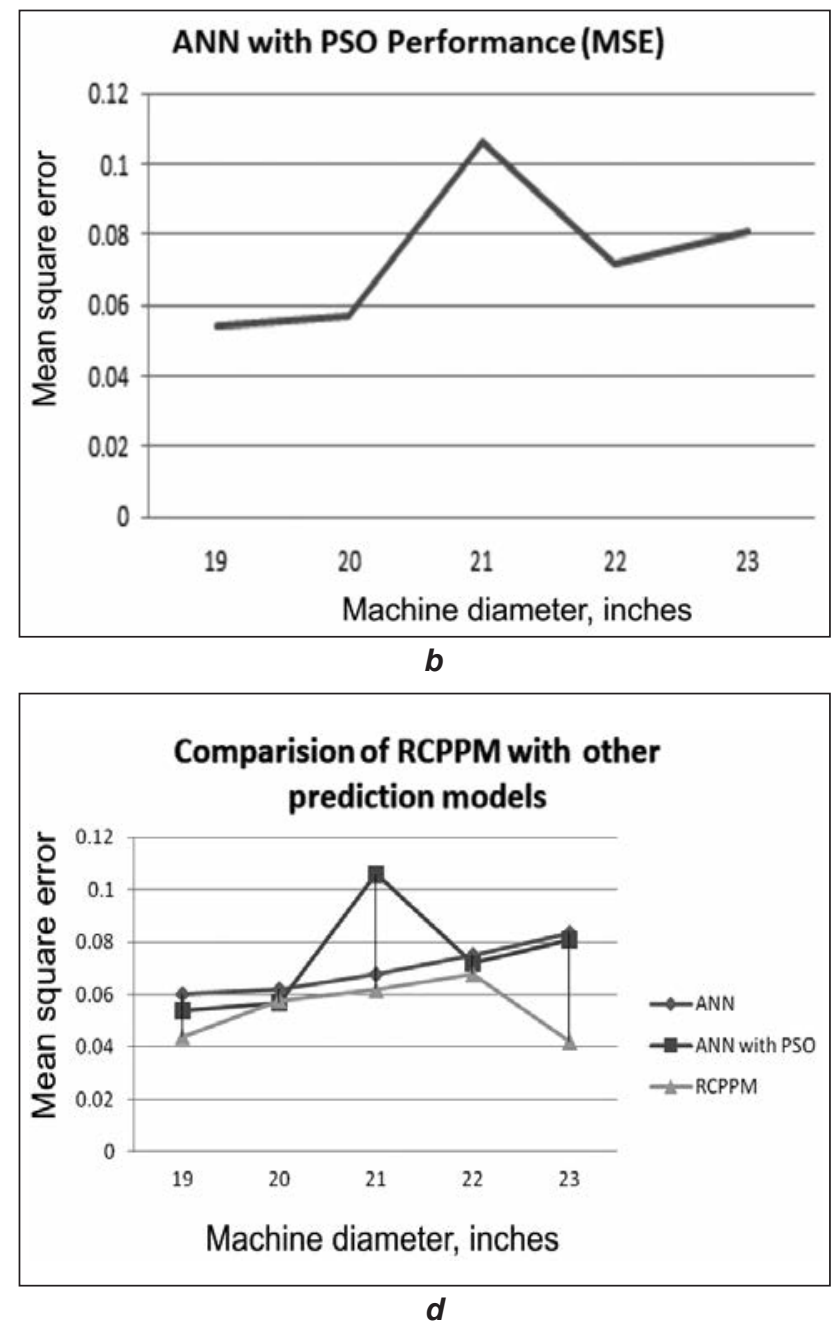

Fig. 4. Dependency of MSE with various approaches: $a-\mathrm{ANN}, b-\mathrm{ANN}$ with PSO, $c-\mathrm{RCPPM}, d-$ comparison of RCPPM with other prediction models 
diameter value is 21 . The performance of the proposed model RCPPM is checked with various machine diameters. The MSE values of the proposed model are less for all the cases of machine diameter compared with ANN and ANN with PSO. The simple ANN model shows a gradual increase in MSE as the machine diameter increases. The ANN with PSO performed on it decreases its error for all machine diameters but one. The comparison graph shows that the proposed RCPPM model outperforms both ANN and ANN with PSO prediction models.

\section{CONCLUSIONS}

Knitted structures offer easy-care property, high elasticity, air permeability, flexibility, etc., in comparison to woven fabrics. During the various stages of knitting, making up and of end use, a lot of problems are encountered. The most important problem is choosing optimum fabric width during the garment manufacturing process. Textile industry needs the model to predict the fabric width accurately to overcome the unwanted textile wastage and provide the smart environment in textile production. In this research work, one of the soft computing techniques namely rough set approach was used for an attribute or feature selection and developed rough computational optimal attribute selection (RCOAS) method to find optimal attributes from a large amount of textile data and its performance is found to be better than those of other existing feature selection methods. Based on the selected optimal attributes, the rough computational based priority prediction model (RCPPM) is developed with the help of Gaussian Naïve Bayes algorithm. This proposed model with the inputs is used to predict fabric width in fabric manufacturing process in the textile domain. Attempts can be made to optimize the developed model further. The results show that the relationship between the predicted width and the measured width is good. The proposed algorithm is tested with real-time textile dataset collected from Tirupur knitting industry and, doubtless, will be of use to manufacturers of the knitted garment. Our future work will be extended to propose a new algorithm for handling big or large textile dataset effectively using Hadoop framework.

\section{REFERENCES}

[1] Gravas, E., Kiekens, P., Langenhove, L., Predicting fabric weight per unit area of single-and double-knitted structures using appropriate software, In: Autex Research Journal, 2006, 6, 4, 223-237

[2] Panda, P.K., Sumanta, B., Single jersey cotton knit: Finished width prediction by ANN, In: The Indian Textile Journal, 2013

[3] Yildirim, P., Birant, D., Alpyildiz, T., Data mining and machine learning in textile industry, In: Wiley Interdisciplinary Reviews: Data Mining and Knowledge Discovery, 2018, 8, 1, 1228

[4] Majumdar, A., Soft computing in fibrous materials engineering, In: Textile Progress, 2011, 43, 1, 1-95

[5] Mozafary, V., Payvandy, P., Application of data mining technique in predicting worsted spun yarn quality, In: The Journal of The Textile Institute, 2014, 105, 1, 100-108

[6] Gsell, E., Heimlich, F., Ehrmann, A., Weber, M.O., Dependence of dry, wet and washing relaxation on knitted structures and fabric parameters, In: Industria Textila, 2017, 68, 2, 121-125, https://doi.org/10.35530// IT.068.02.1333

[7] Akyol, U., Tüfekci, P., Kahveci, K., Cihan, A., A model for predicting drying time period of wool yarn bobbins using computational intelligence techniques, In: Textile Research Journal, 2015, 85, 13, 1367-1380

[8] Matusiak, M., Application of artificial neural networks to predict the air permeability of woven fabrics, In: Fibres \& Textiles in Eastern Europe, 2015

[9] Golob, D., Osterman, D.P., Zupan, J., Determination of pigment combinations for textile printing using artificial neural networks, In: Fibres \& Textiles in Eastern Europe, 2008, 16, 3, 68

[10] Furferi, R., Governi, L., Volpe, Y., Modelling and simulation of an innovative fabric coating process using artificial neural networks, In: Textile Research Journal, 2012, 82, 12, 1282-1294

[11] Przybyła-Kasperek, M., Feature selection based on the rough set theory and dispersed system with dynamically generated disjoint clusters, In: INnovations in Intelligent SysTems and Applications (INISTA), 2017, IEEE International Conference, 223-228

[12] Elzaher, Eltahan, E.A., Sultan, M., Mito, A.B., Determination of loop length, tightness factor and porosity of single jersey knitted fabric, In: Alexandria Engineering Journal, 2016, 55, 2, 851-856

[13] Kalkanci, M., Sinecen, M., Kurumer, G., Prediction of dimensional change in finished fabric through Artificial Neural Networks, In: Tekstil Ve Konfeksiyon, 2018, 28, 1, 51-60

[14] Hossain, A.M., Kabir, A.Z., Customization of Starfish technology in the production of cotton-knit fabrics: A practical approach, In: International Journal of Engineering \& Technology, 2011, 11, 1, 125-139

[15] Anbumani, N., Knitting Fundamentals, Machines, Structures and Developments, In: New Age International Publishers, 2006

[16] Pawlak, Z., Rough set theory and its applications to data analysis, In: Cybernetics \& Systems, 1998, 29, 7, 661-688

[17] Pawlak, Z., Skowron, A., Rudiments of rough sets, In: Information sciences, 2007, 177, 1, 3-27 
[18] Thangavel, K., Pethalakshmi, A., Dimensionality reduction based on rough set theory: A review, In: Applied Soft Computing, 2009, 9, 1, 1-12

[19] Eldessouki, M., Hassan, M., Qashqary, K., Shady, E., Application of principal component analysis to boost the performance of an automated fabric fault detector and classifier, In: Fibres \& Textiles in Eastern Europe, 2014, 22, 51-57

[20] Li, C.H., Kuo, B.C., Lin, C.T., LDA-based clustering algorithm and its application to an unsupervised feature extraction, In: IEEE Transactions on Fuzzy Systems, 2011, 19, 1, 152-163

[21] Arthi, K., Tamilarasi, A., Prediction of autistic disorder using neuro fuzzy system by applying ANN technique, In: International journal of developmental neuroscience, 2008, 26, 7, 699-704

[22] Ding, W., Lin, C.T., Prasad, M., Cao, Z., Wang, J., A Layered-Coevolution-Based Attribute-Boosted Reduction Using Adaptive Quantum-Behavior PSO and Its Consistent Segmentation for Neonates Brain Tissue, In: IEEE Transactions on Fuzzy Systems, 2018, 26, 3, 1177-1191

\section{Authors:}

\section{BHUVANESHWARRI ${ }^{1}$, A. TAMILARASI ${ }^{2}$}

${ }^{1}$ Ph.D., Research Scholar in Information and Communication Engineering, Anna University, Chennai - 600 025, TAMILNADU, INDIA

Assistant Professor (Senior), Department of IT, Institute of Road and Transport Technology,

Vasavi college post, Erode - 638 316, INDIA

e-mail: pbw.irtt@gmail.com

${ }^{2}$ Professor \& Head, Department of Computer Applications, Kongu Engineering College,

Perundurai, Erode - 638 060, INDIA

e-mail: drtamil@kongu.ac.in

Corresponding author:

I. BHUVANESHWARRI

e-mail: pbw.irtt@gmail.com 